\title{
Imagem de fantasma
}

para apichatpong weerasethakul e davi kopenawa yanomami

\section{Imagem (1)}

Esperando o sinal vermelho; uma imagem sem idade paira ao seu lado. Nenhum calor a acompanha; nem efeito sonoro. Há uma transparência que o faz ver além; ainda assim não é uma silhueta. Somente uma imagem; aproveitando sua falta de luz. Talvez pra esconder cabelos quebradiços; ou ferimento de bala. Uma armadura dourada duplicando o seu peso; um sorriso convincente. A imagem também oculta a própria sombra; como se dobrar um véu fosse possível. Quando se guardava num corpo, sua sombra era fardo maior; a imagem se arrastava entre os cantos do palácio. Agora é vagante; livre dessas cordas apertadas (como o ato de respirar há muito esquecido). Sem tirar o olhar do semáforo, é com o canto do olho que observa; o verde ainda permanece. Talvez na presença da imagem, o tempo se estude; como quando alguém junta um pouco a cada dia no canto da parede até que algo aconteça. A imagem agora, como quando não tinha corpo onde se hospedar, quando todas flutuavam e não existia palavra que simbolizasse o ato de firmar os pés no chão, a imagem agora antecede um forte desejo de ser vista; mal sabe ela que está sendo, com o canto dos olhos, por um olhar sorrateiro, atento, por um olhar rasgado, semitransparente. Parte desse olhar começa a sair do par de olhos; se amontoa no lixo invisível, gruda noutra pele. 
REDE INTERNACIONAL LYRACOMPOETICS

Imagem (2)

a sombra de michael myers e as penas brancas da arara têm o mesmo peso

\title{
Imagem (3)
}

isso não vai pro tik tok

é o passar a vista a olhadela

sem viralizar é o vir à página

um ancestral nas suas costas

\author{
Imagem (4) \\ Ele diz: \\ - até fazer do mundo meu espelho \\ (tal-vez) \\ e depois quebrá-lo, \\ (como se fosse possível) \\ sentir o gosto de sangue \\ (para um fantasma) \\ pela última vez. \\ (Não é)
}




\section{Imagem (5)}

antropoceno

palavra tão bonita

se cair de novo este céu apático

qual será a cor do pôr-do-sol amanhã

não se esconde mais nenhum verso

no ar soçobram cânticos vestígios

de seda caixotes de máquinas

vê só a constelação de papagaios

indo embora indo embora

ouve quanto sussurro

NOTA

* Lucas Litrento é escritor, realizador cinematográfico e produtor cultural, vive em Maceió/AL. Lançou os livros Os meninos iam pretos porque iam (Imprensa Oficial Graciliano Ramos, 2019), ROBYN (1TXW, 2020), zine de poesia, e TXOW (Edipucrs, 2020). Realizou o curta-metragem círculos (1TXW, 2020). 